\title{
Scent or movement of Varroa destructor mites does not elicit hygienic behaviour by Africanized and Carniolan honey bees
}

\author{
Pia AumeIER ${ }^{\mathrm{a}, \mathrm{b} *}$, Peter RosenKRANZ ${ }^{\mathrm{b}}$ \\ a Zoologisches Institut, Auf der Morgenstelle 28, 72076 Tübingen, Germany \\ ${ }^{\mathrm{b}}$ Landesanstalt für Bienenkunde, Universität Hohenheim, August-von-Hartmannstr. 13, \\ 70593 Stuttgart, Germany
}

(Received 20 October 2000; revised 19 February 2001; accepted 1 March 2001)

\begin{abstract}
Hygienic behaviour of mite-tolerant Africanized and susceptible Carniolan colonies was evaluated in Brazil by sham-manipulating or artificially inoculating 4175 capped worker brood cells with dead Varroa destructor mites or ants, or their odour extracts. Both bee types expressed the hygienic components 'uncapping', 'removal of introduced mite/ant' and 'removal of brood' to the same extent and pattern. The similar response to dead mites of different origins and solvent-extracted mites indicates a minor role of scent or of movement of mites within sealed brood cells as releasers of hygienic behaviour. However, application of dichlormethane-extract of mites increased the hygienic response compared to pure solvent alone. Hygienic reactions to mite infested brood cells must, therefore, be elicited by other signals, possibly by the detection of specific reactions or odours of the infested larvae or pupae.
\end{abstract}

brood removal / scent cues / Varroa destructor / varroosis tolerance / Africanized honeybee / Apis mellifera carnica

\section{INTRODUCTION}

The classical studies of hygienic behaviour by Rothenbuhler (1964) demonstrated a genetic basis to the variation among colonies in their removal of American foulbrood (Palacio et al., 2000). Current studies on hygienic behaviour focus on the importance of this trait for tolerance to Varroa destructor Anderson and Trueman (Vandame, 1996; Boecking and Drescher, 1998; Spivak and Reuter, 1998; Rosenkranz,

* Correspondence and reprints

E-mail: bieneau @ uni-hohenheim.de 
1999; Aumeier et al., 2001). According to recent publications, hygienic reactions towards Varroa destructor in capped brood cells contributes to a colony's tolerance of these mites, although overall tolerance is evidently a multifactorial trait (Boecking and Spivak, 1999; Rosenkranz, 1999; Rosenkranz et al., 1997).

Up to now, little is known about the stimuli releasing hygienic reactions by the broodattending worker bees. In principle, both mechanical and chemical stimuli could be the source of the releasers, potentially originating from both the brood and from the parasite (Masterman et al., 2000; Nation et al., 1992). In the original host of $V$. destructor (Anderson, 2000; Anderson and Trueman, 2000), the Asian hive bee Apis cerana Fabr., alien scent adhering to mites was found to elicit hygienic behaviour (Rosenkranz et al., 1993).

In this study, we examined the role of movement and scent produced by Varroa destructor in stimulating removal of capped worker brood by colonies of Apis mellifera $\mathrm{L}$. As it has been demonstrated that the Africanized honey bees in Brazil are more effective in removing mites from their colonies relative to European strains of A. mellifera (Guerra et al., 2000; GuzmanNovoa et al., 1999), we performed a comparative study with Carniolan and Africanized bees at a tropical site in Brazil to elucidate cues that might elicit different removal behaviour, and thus differences in mite tolerance between the two bee types.

\section{MATERIALS AND METHODS}

\subsection{Study site, bees and mites}

Experiments were performed during the summer, January and February, of 1996 in the apiary of the Dept. of Genetics, University of São Paulo in Ribeirão Preto, Brazil. All colonies were maintained in Langstroth hives, containing 3-5 brood combs and were fed ad libitum with sugar water and pollen.
We compared four colonies of Africanized and four of Carniolan bees, the latter headed by imported $A$. $m$. carnica queens mated at Hohenheim, Germany. All colonies were infested with mites of local Brazilian origin (Anderson, 2000; Anderson and Trueman, 2000; Aumeier et al., 2001). However, for artificial brood cell infestation we also used freeze-killed mites imported from Germany. In contrast to the Africanized colonies, the Carniolan colonies became noticeably weak and, after a few months, died probably because of a high mite infestation and an insufficient adaptation to the tropical environmental conditions.

\subsection{Experimental design}

For artificial infestation, wax caps of justsealed worker brood cells, approximately $24 \mathrm{~h}$ after cell sealing and containing prepupae, were opened along one edge using solvent-washed forceps. Dead female mites were carefully introduced into a cell on the tip of a sterilised needle. All target mites were placed on the ventral side of the prepupa without harming the host. When testing extracts, dissolved compounds were applied directly onto a prepupa. Cells were resealed by using a drop of warm wax. In the controls, cells were sham-manipulated without inserting a mite or solvent. Ten to 100 cells, randomly selected in the centre of a brood comb, were treated in sequence. Immediately after handling, combs were replaced into their original colonies. Three days later, a total of 3645 artificially infested brood cells and 530 control cells were inspected. Cells were marked and identified by use of a transparent plastic sheet.

As our first results revealed a moderate hygienic reaction towards introduced dead mites, we tested whether bees would respond more intensely to other intruders by using freeze-killed worker ants of a Monomorium species commonly occurring at the study site (Tab. Ib). 
Table I. Test series performed for the evaluation of hygienic behaviour. Mites and ants were introduced into sealed brood cells, extracts were applied directly on the prepupa.

\begin{tabular}{|c|c|c|c|}
\hline Target / application & \multicolumn{2}{|c|}{ Status } & Origin of mites \\
\hline \multirow[t]{2}{*}{ (a) Phoretic female mites } & \multicolumn{2}{|l|}{ dead (freeze-killed): } & Carniolan colony, Germany \\
\hline & solvent-washed: & $\begin{array}{l}1 \text { month } \\
3 \text { months/3 times }\end{array}$ & Carniolan colony, Germany \\
\hline (b) Ants & \multicolumn{2}{|l|}{ dead (freeze-killed): 1} & \\
\hline (c) Solvents & \multicolumn{2}{|c|}{$\begin{array}{l}\mathrm{P}=\text { pentane } \\
\mathrm{DCM}=\text { dichlormethane }\end{array}$} & \\
\hline \multirow[t]{2}{*}{ (d) Extracts } & mites extracted: & $\begin{array}{l}1 \text { week with P } \\
1 \text { week with DCM }\end{array}$ & \\
\hline & ants extracted: & 1 week with $P$ & \\
\hline
\end{tabular}

\subsection{Testing of assumed releasers of hygienic reactions}

The effect of parasite movements on host removal reactions was studied by introduction of dead mites, obtained by freezekilling. The role of scent cues was tested by applying mites from different countries and different host colonies. Furthermore solvent-washed (= odour-free) mites and mite extracts were used (Tab. Ia). To produce odour-free mites, volatiles were removed by pentane treatment for one month or repeated washing in pentane and dichlormethane for three months.

Scent of brood cell intruders was obtained by pentane or dichlormethane extraction for one week (Tab. Id). In the bioassay, equivalents of three mites or one or three ants dissolved in $5 \mu \mathrm{l}$ pentane were applied directly to a pupa using a Hamilton syringe. To evaluate the effect of pure solvent, $5 \mu$ of pentane or dichlormethane was used (Tab. Ic).

\subsection{Evaluation of the experiments}

Hygienic behaviour was evaluated by recording the percent of artificially manipulated brood cells which had been responded to by the bees. We distinguished the following states of brood cells: untouched, cell cap merely opened ('cell cap opened'), introduced mite/ant removed but brood still present and resealed ('only introduced mite/ant removed'), or brood completely or partially removed ('brood removed'). Every seemingly untouched sealed brood cell was opened, the pupa was removed by forceps, and the cell walls were carefully examined to verify the presence of the introduced mite or ant. From a total of 1821 analysed brood cells artificially infested with dead mites, only 7 were found to be spun into the cell cocoon. These rare cases were excluded from analysis as nurse bees can not perform any hygienic reactions on these mites.

\subsection{Data analysis}

Data were arcsine transformed so that they conformed to the assumptions of ANOVA. To demonstrate whether there was variation among the colonies (i.e. colonies with extreme high or low hygienic ability, respectively) we compared the hygienic 
reactions of the single colonies (sum of all reaction components, three repetitions) by a one way ANOVA. As variation among colonies was not significant (see Sect. 3.3), the results were pooled among Africanized and among Carniolan colonies for further analysis. We used a design of colonies nested within bee type and analysed the data by two-way ANOVAs with treatment and bee type (Africanized/European) as the fixed main effects. All statistical tests were performed using the software modules of Statistica (StatSoft, 1994) and Microstat (Ecosoft, 1984).

\section{RESULTS}

\subsection{Treatment effects}

The experimental manipulation of the cell cap without introduction of a mite or solvent (= control, Fig. 2 ) released hygienic reactions toward about $6 \%$ of brood cells in Africanized and $4 \%$ in Carniolan colonies.

\subsection{Different components of hygienic behaviour}

In only a few cells, merely the wax cap was manipulated or removed by the bees (Fig. 1). The dead mite was missing in about one third of the artificially infested cells, and the cell had been properly resealed by the bees. About half of the cells were treated in this way by the bees when dead ants were introduced in the brood cells. In a minor fraction of cases, cells were found completely emptied, thus showing the full removal response. In both bee types, 'only introduced mite/ant removed' was found to be the main component of hygienic behaviour.

\subsection{Mite properties and the reaction of the bees}

Artificial introduction of mites provoked hygienic behaviour (summing all reaction components mentioned above) with frequencies between $29 \%$ and $36 \%$ for the

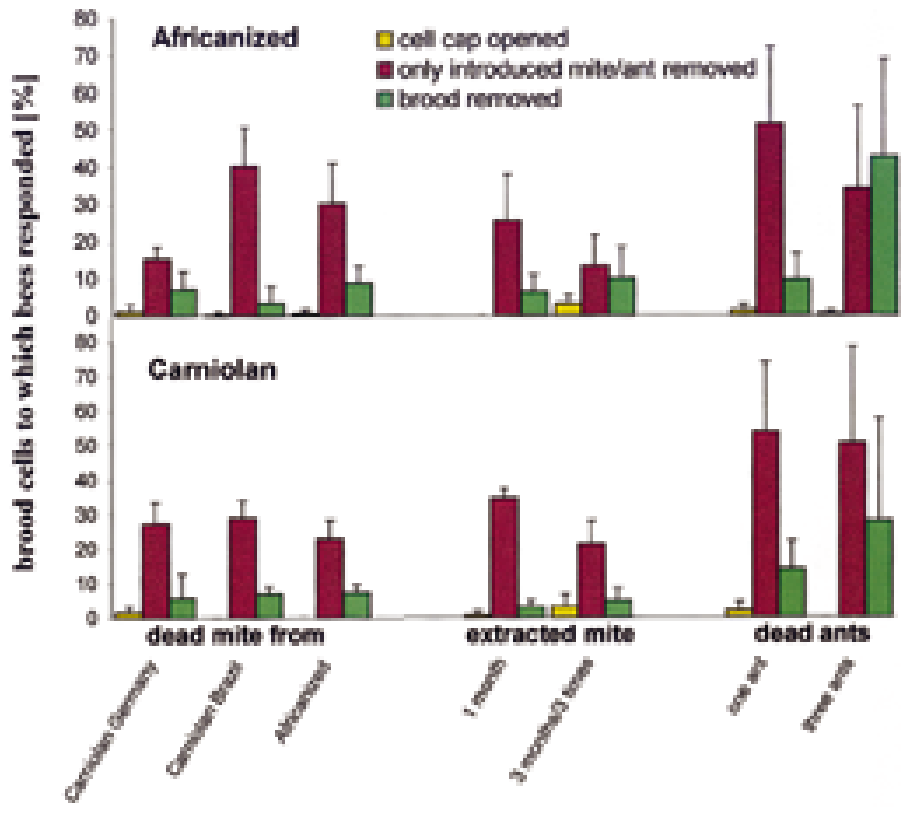

Figure 1. Component of hygienic behaviour (mean \pm SD) in Africanized and Carniolan colonies (for summarised results, see Figs. 2 and 4). Mite or ant removal and subsequent resealing of the intact brood is the predominant response to artificially infested cells in both bee types. 
Figure 2. Hygienic behaviour (mean $\pm \mathrm{SD}$ of sum of all behavioural components) against dead mites (' $n$ ' = number of manipulated brood cells).
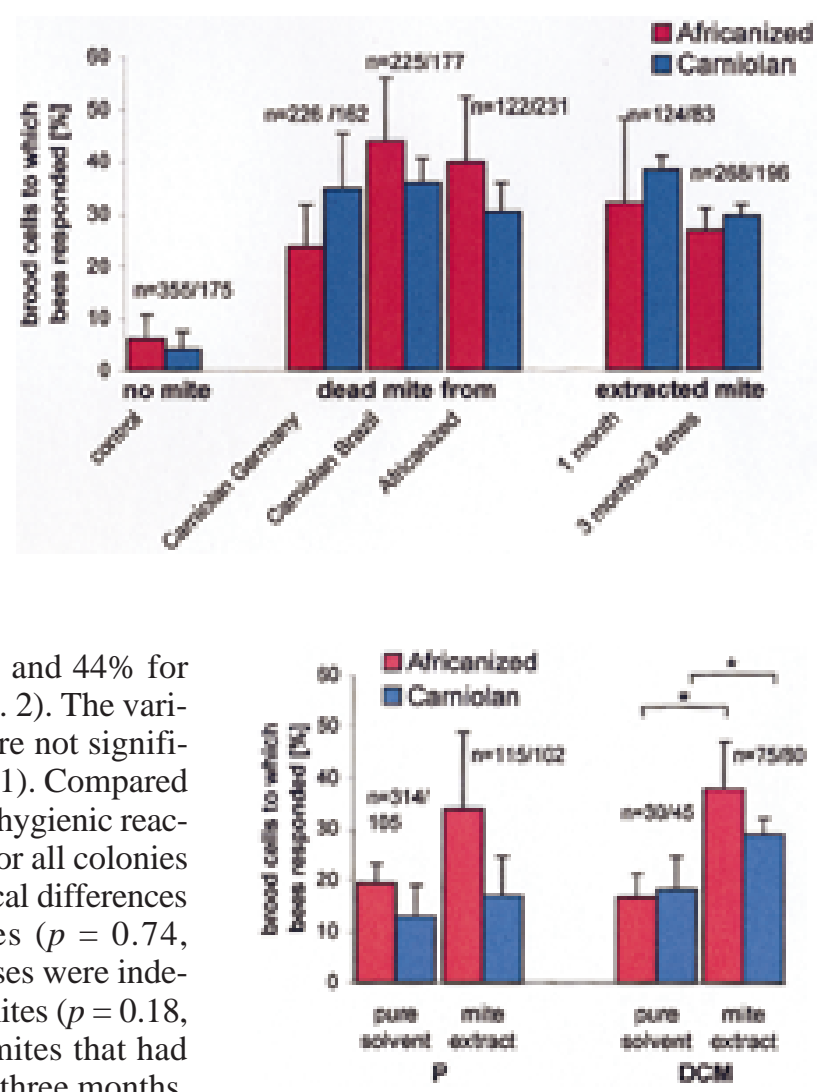

Figure 3. Increase in hygienic behaviour (mean \pm SD of sum of all behavioural components) after application of solvent extracts of mites in comparison to solvent $(\mathrm{P}=$ pentane, $\mathrm{DCM}=$ dichlormethane, ' $\mathrm{n}$ ' = number of manipulated brood cells). ${ }^{*} p<0.01$.

\subsection{Hygienic reactions towards other brood cell intruders}

Compared to the experiments performed with introduced mites (compare Fig. 2), dead ants released a high removal response in both Africanized and Carniolan colonies (Fig. $4 ; p<0.01$ ), independent of bee type $(p=0.63, F=0.16, d f=1)$. However, application of pentane extract of ants did not increase hygienic reactions relative to pure pentane $(p=0.36, F=0.95, d f=1)$, a lack of difference that was independent of bee 


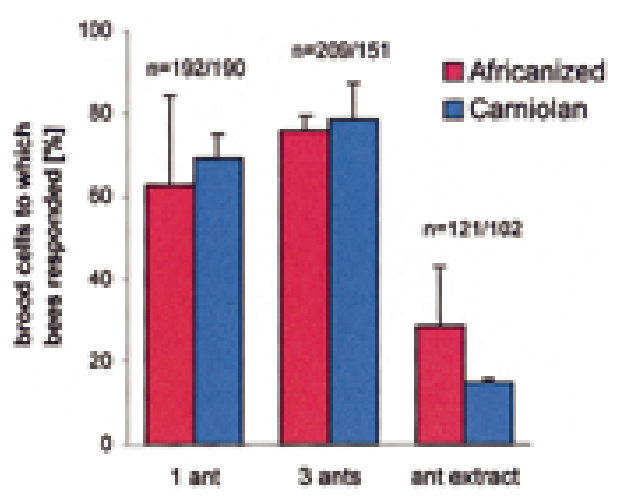

Figure 4. Dead ants artificially introduced into brood cells released intense hygienic behaviour (mean \pm SD of sum of all behavioural components) in both Africanized and Carniolan honey bee colonies. Application of pentane extract of these ants did not elicit a greater hygienic response compared to solvent treatment (see Fig. 3: 'P, solvent', $p=0.36, F=0.95, d f=1$ ).

type $(p=0.11, F=3.18, d f=1)$. The interaction term was not significant $(p=0.71$, $F=0.15, d f=1)$.

\section{DISCUSSION}

\subsection{The experimental set up}

The degree of mite-specific hygienic behaviour of honey bee colonies was tested by artificial infestation of mites into capped brood cells. This method is widely used, even if the manipulation of the brood cells may elicit higher removal rates compared to naturally invaded brood cells (Boecking and Spivak, 1999). However, the very low rate of removal in the sham-operated cells demonstrated that the experimental manipulation did not provoke removal reactions, exceeding the average cannibalism rate against untreated cells (Boecking and Ritter, 1993). For artificial infestation we only used phoretic mites, representing the natural invading mites, and cells containing an early prepupa to prevent the larva from spinning a cocoon around the introduced subjects. As the maximal response towards artificially infested brood cells was evident within three days of treatment (Aumeier et al., 2001), all tests were evaluated after this time period.

\subsection{Different components of hygienic behaviour}

Most studies on mite-specific hygienic behaviour only focus on brood removal (reviewed in Boecking and Spivak, 1999). Our study, however, strongly indicates a more complex combination of behavioural components. From approximately one third of brood cells infested with dead or extracted mites, the mite disappeared, but only $10 \%$ of the infested pupae was removed by the bees. This was also confirmed by similar experiments with live mites (Aumeier et al., 2001). In the case of live mites, some of them may have actively escaped from uncapped brood cells (Bär and Rosenkranz, 1992; Boecking, 1994). However, in A. mellifera, the mites only left brood cells when the bees had already removed most of the larval or pupal body (Boecking, 1994; Boecking and Drescher, 1998). The dead mites in the present study must have been removed by the bees. Thus, the definition of hygienic behaviour as 'uncapping and removal of dead, diseased or parasitized brood' (Arathi et al., 2000) only in part reflects the response of adult bees to mite-infested brood cells. 'Mite-only removal' without damaging the host may be an adaptive strategy to minimise the loss of brood. If the $V$. destructor female is removed shortly after invasion of the brood cell, even secondary infections transmitted by the mite (Brødsgaard et al., 2000) may be prevented. The complexity of the mite-specific removal behaviour may have consequences for selective breeding practices. Hygienic behaviour has become a favourite trait in programmes to breed mite tolerant strains of European honey bees (Boecking and Drescher, 1998; Spivak and Reuter, 1998). Several assays have been described to quantify the hygienic properties of a colony, of which the frozen brood test or the pin test is now widely used (Boecking 
and Spivak, 1999; Gramacho et al., 1997, 1999; Spivak and Downey, 1998). However, these methods only use one or a few components of the hygienic behaviour performed towards mite-infested brood cells. A bioassay that also includes the 'mite-only removal' might be more effective in selecting mite-specific hygienic honey bees.

\subsection{Stimuli inducing hygienic behaviour}

\subsubsection{Importance of mite status}

Bees responded to dead mites to the same degree as live mites (brood cells artificially infested with one live mite were responded to in $24.2 \%$ to $44.1 \%$ by Africanized bees and $30 \%$ to $37.5 \%$ by Carniolan bees (Aumeier et al., 2001). This clearly indicates that movement and other activities of the mite within the sealed brood cell was not a crucial trigger to elicit hygienic behaviour in our experiments. Thus, we could not confirm previous studies which assumed a correlation between removal response and live status of the mite (Rosenkranz et al., 1993; Boot et al., 1999).

\subsubsection{Chemical detection of introduced targets}

According to our results with live mites of Africanized and Carniolan type (Aumeier et al., 2001), the origin of the artificially introduced mites did not influence the hygienic response. A possible hive-specific chemical camouflage of the mites (Nation et al., 1992) is, therefore, not crucial for the detection of the parasite in sealed brood cells. This is in contrast to data obtained with A. cerana colonies (Rosenkranz et al., 1993).

Furthermore, solvent-extracted mites elicited a similar removal response compared to untreated mites. As our extraction method ensures the removal of at least nearly all volatile substances, this indicates a recognition mechanism of mite infested brood cells independent from mite scent (Boecking and Drescher, 1994). However, the application of mite extracts elicited a somewhat higher response compared to the pure solvent. These differences were only significant when using DCM extracts, probably because this solvent extracts the polar fraction of the cuticle more effectively than pentane (Aumeier, in prep.). Therefore, an effect of mite scent cannot be completely excluded. However, this polar fraction could be the only source for mite specific cues as the unpolar cuticular hydrocarbon pattern of mites is known to be similar to those of pupae (Nation et al., 1992). In the case of unusual brood cell intruders, odour cues might be more important as indicated by our experiments with dead ants. Our results also indicate that Africanized bees are more sensitive to the application of the mite scent (Figs. 3, 4). A clear reaction to the odour of mites was also confirmed for A. cerana in India (Rosenkranz et al., 1993; Boot et al., 1999).

\subsubsection{Host derived detection cues?}

Bees are obviously able to detect 'suspicious' brood cells. This includes miteinfested cells and those with dead, sick or otherwise manipulated brood (Rothenbuhler, 1964; Gramacho et al., 1997, 1999). It is not clear whether similar mechanisms exist for the detection of dead, diseased and parasitized brood as for the detection of miteinfested cells. In the case of mite-infested brood in A. mellifera colonies, however, the scent or signs of life of the parasite appear to have low importance as recognition cues. Detection of mite-infested brood may be independent from wounding or virus-vectoring by the mite or resulting reactions and odours of the pupae. In further experimental setups we should determine whether mite infestation of a brood cell provokes altered behaviours of the larvae or pupae or induces the release of certain pheromones, and how adult bees perceive such suspected 'stress reactions' of the brood. 


\subsection{Sensitivity of Africanized and Carniolan bees}

Africanized and Carniolan honey bees performed hygienic behaviour towards brood cells infested with dead mites in the same manner and to a similar extent. Slight differences could only be recorded in the somewhat more sensitive recognition of mite volatiles by Africanized bees. We can conclude that the mechanisms for detection and removal of mites are more complex than hygienic behaviour to diseased brood, as first described by Rothenbuhler (1964) and successfully used in selection of American foulbrood resistant bees.

\section{ACKNOWLEDGEMENTS}

We would like to thank Wolf Engels who provided helpful suggestions on the manuscript and Robert Paxton for critical reading and his valuable comments. This study resulted from a Probral project within the DAAD/CAPES agreement.

Résumé - L'odeur et le mouvement de Varroa destructor ne provoquent pas le comportement hygiénique chez les abeilles africanisées et carnoliennes. Le comportement hygiénique des abeilles domestiques (Apis mellifera L.) est connu comme moyen efficace de défense contre la loque américaine et d'autres maladies du couvain. Des études récentes ont montré l'importance de ce comportement dans la tolérance à l'acarien Varroa destructor (Vandame, 1996 ; Boecking et Drescher, 1998 ; Spivak et Reuter, 1998 ; Aumeier et al., 2001). On dispose néanmoins de peu d'informations concernant les stimuli qui déclenchent les réactions hygiéniques. Les ouvrières qui s'occupent du couvain pourraient être attirées par des signaux mécaniques et chimiques provenant à la fois du couvain et du parasite (Nation et al., 1992 ; Masterman et al., 2000). Afin d'évaluer l'influence du mouvement de l'acarien sur la détection par l'hôte des cellules infestées, nous avons infesté artificiellement, avec des acariens $V$. destructor morts, des cellules de couvain operculé d'ouvrières de quatre colonies d'abeilles africanisées et de quatre colonies d'Apis mellifera carnica, élevées sous le climat tropical du Brésil. Pour tester l'influence de l'odeur de l'acarien, nous avons utilisé des femelles de $V$. destructor de différentes origines (pays et colonies hôtes diverses), des acariens sans odeur (odeurs extraites par solvant) et des extraits cuticulaires. Des ouvrières de fourmis de l'espèce Monomorium, tuées par le froid, ont été introduites pour étudier la réaction à un intrus inhabituel des cellules de couvain. Trois jours après l'infestation, nous avons enregistré si les cellules de couvain n'étaient «que» désoperculées, si les acariens/fourmis introduits ou les nymphes avaient été éliminés et nous avons comparé les résultats avec ceux obtenus récemment au même endroit avec des acariens vivants (Aumeier et al., 2001). Au total 4175 cellules de couvain manipulées ont été étudiées.

Une forte proportion des acariens introduits a disparu des cellules de couvain artificiellement infestées sans dommage causé aux nymphes (Fig. 1). L'ouverture de la cellule et l'élimination du couvain sont visiblement des étapes, indépendantes l'une de l'autre, d'une réaction progressive des abeilles adultes aux cellules de couvain infestées.

L'origine des acariens n'a pas eu d'influence sur le comportement hygiénique (fourchette de 24 à $44 \%, p=0,165$, Fig. 2). L'extraction par solvant des acariens durant un à trois mois n'a pas non plus diminué le taux de réaction (fourchette de 27 à $38 \%, p=0,34$ ). Le mode et l'étendue de la réaction hygiénique étaient semblables à ceux dirigés contre des acariens vivants (Aumeier et al., 2001). Les mouvements ou l'odeur des acariens (Rosenkranz et al., 1993 ; Boot et al., 1999) à l'intérieur des cellules de couvain operculé ne constituent pas à l'évidence un facteur crucial pour le déclenchement du comportement hygiénique spécifique des acariens. Pourtant, des pré-nymphes traitées 
au dichlorméthane ont provoqué significativement plus de réponses que le solvant pur (Fig. 3, $p=0,007$ ) chez les deux types d'abeilles. Une action de l'odeur des acariens comme signal de reconnaissance pour les ouvrières ne peut donc pas être totalement exclue. Les taux élevés de réaction hygiénique envers les cellules infestées par les fourmis indiquent également une action de l'odeur : presque toutes les pré-nymphes infestées avec des fourmis mortes ont réagi (Fig. 4, 63-79\%, $p<0,01$ ).

Mais, dans le cas des cellules infestées par les acariens, le rôle des autres stimulus déclenchant le comportement hygiénique doit être établi. Une hypothèse est que la modification du comportement des larves ou des nymphes parasitées peut être perçue par les nourrices et servir de déclencheur pour le comportement hygiénique.

Le mode et l'étendue des réactions hygiéniques n'ont pas différé significativement d'un type d'abeilles à l'autre. La détection et la réaction hygiénique aux cellules infestées semble être similaire chez les colonies d'abeilles africanisées et les colonies de carnoliennes, au moins au Brésil. Ceci est également confirmé par les faibles différences observées lors de nos expériences avec des acariens vivants (Aumeier et al., 2001). Le comportement hygiénique ne peut donc expliquer à lui seul les différences de sensibilité des deux types d'abeilles à $V$. destructor.

Varroa destructor / sensibilité-tolérance / varroose / comportement hygiénique / signal olfactif / abeille africanisée / $A . m$. carnica

Zusammenfassung - Geruch oder Bewegung von Varroa destructor sind keine Auslöser für das Hygieneverhalten bei Afrikanisierten oder Carnica- Honigbienen. Durch ihr Hygieneverhalten können Honigbienen effektiv die Ausbreitung von Amerikanischer Faulbrut und anderen Brutkrankheiten eindämmen. Obwohl aktuelle
Untersuchungen sich auch mit der Bedeutung dieses Verhaltens für die VarroatoseToleranz beschäftigen (Vandame, 1996; Boecking und Drescher, 1998; Spivak und Reuter, 1998; Aumeier et al., 2001), ist bisher wenig über die auslösenden Signale bekannt. Dies könnten sowohl mechanische, als auch chemische Reize von Brut oder Parasit (Nation et al., 1992; Masterman et al., 2000) sein. Um die Bedeutung der Milben-Bewegung für das Auffinden infizierter Zellen abzuschätzen, wurde im tropischen Brasilien verdeckelte Brut von 4 Afrikanisierten und 4 Apis mellifera carnica Völkern künstlich mit toten Varroa destructor-Milben infiziert. Der Effekt von Milben-Duft wurde durch Einbringen von Varroa-Weibchen unterschiedlicher Herkunft (unterschiedliche Länder und Wirtsvölker), sowie lösungsmittelextrahierter Milben (= duft-frei) und von Cuticula-Extrakten von Milben überprüft. Tote Ameisen-Arbeiterinnen einer Monomorium Art wurden als natürlicherweise nicht in Brutzellen vorkommende Eindringlinge eingesetzt. Drei Tage nach der Infektion wurde erfasst, ob die Zellen "nur" entdeckelt worden waren, oder ob die eingesetzten Milben/Ameisen oder die Puppe fehlten und die Ergebnisse mit denen für lebende Milben am selben Versuchsort (Aumeier et al., 2001) verglichen. Insgesamt wurden 4175 manipulierte Brutzellen ausgewertet.

Zu einem hohen Anteil verschwanden künstlich eingesetzte Milben aus den Brutzellen, ohne sichtbare Verletzungen der Bienenbrut (Abb. 1). Das Öffnen der Zelle und das Ausräumen von Bienenbrut sind offensichtlich voneinander unabhängige Stufen der Adultbienen-Antwort gegenüber milben-infizierten Zellen.

Die Milbenherkunft beeinflusste das Hygieneverhalten nicht (zwischen 24 und $44 \%$, $P=0,165$, Abb. 2). Auch ein- bzw. dreimonatige Lösungsmittelextraktion der Milben konnte die Reaktionen nicht reduzieren (zwischen 27 und $38 \%, P=0,34)$. Muster und Intensität des hygienischen Verhaltens entsprachen denen gegenüber lebenden Milben 
(Aumeier et al., 2001). Bewegungen oder der Geruch der Milben (Rosenkranz et al., 1993; Boot et al., 1999) innerhalb verdeckelter Brutzellen scheinen daher keine für das Auslösen Milben-spezifischer Putzreaktionen essentiellen Faktoren zu sein. Dennoch wurden in beiden Bienentypen Vorpuppen, die mit Dichlormethan-Extrakt von Varroa-Milben behandelt worden waren stärker gereinigt als Puppen mit reinem Lösungsmittel (Abb. 3, $P=0,007$ ). Daher kann nicht ausgeschlossen werden, dass Milbenduft von Ammenbienen zur Erkennung verwendet wird. Darauf weisen auch die hohen Werte der mit Ameisen infizierten Zellen hin (Abb. 4, 63-79 \%, P<0,01). Im Fall von mit Milben infizierten Brutzellen muss jedoch auch die Bedeutung anderer Stimuli für das Auslösen des Hygieneverhaltens erwogen werden. Es wird diskutiert, ob ein verändertes Verhalten parasitierter Larven oder Puppen als Auslöser für Hygieneverhalten von Ammenbienen wahrgenommen werden könnte.

Beide untersuchten Bienentypen unterschieden sich am Untersuchungsort in Brasilien nicht signifikant in Muster und Ausmass der hygienischen Reaktionen, was auf ähnliche Mechanismen des Auffindens und Verhaltens gegenüber infizierten Brutzellen schliessen lässt. Diese nur geringen Unterschiede im Hygieneverhalten zwischen Afrikanisierten und Europäischen Bienen wurden auch für den künstlichen Einsatz lebender Milben beobachtet (Aumeier et al., 2001). Die unterschiedliche Anfälligkeit beider Bienentypen gegenüber der Varroatose kann daher vermutlich nicht alleine durch ihr Hygieneverhalten erklärt werden.

\section{Ausräumverhalten / Duftstoffe / Afrika- nisierte Honigbiene / Varroa destructor / Varroatose-Toleranz / Apis mellifera carnica}

\section{REFERENCES}

Anderson D.L. (2000) Variation in the parasitic bee mite Varroa jacobsoni Oud., Apidologie 31, 281-292.
Anderson D.L. Trueman J.W.H. (2000) Varroa jacobsoni (Acari: Varroidae) is more than one species, Exp. Appl. Acarol. 24, 165-189.

Arathi H.S., Burns I., Spivak M. (2000) Ethology of hygienic behaviour in the honey bee Apis mellifera L. (Hymenoptera: Apidae): Behavioural repertoire of hygienic bees, Ethology 106, 365-379.

Aumeier P., Rosenkranz P., Gonçalves L.S. (2001) A comparison of the hygienic response of Africanized and European (Apis mellifera carnica) honey bees to Varroa-infested brood in tropical Brazil, Genet. Mol. Biol., in press.

Bär E., Rosenkranz P. (1992) Spezifisches Putzverhalten von Honigbienen (Apis mellifera) unterschiedlicher Rassen gegenüber Varroainfizierten Brutzellen, Ann. Univ. Mariae Curie Sklodowska 47, 1-6.

Boecking O. (1994) The removal behavior of Apis mellifera $\mathrm{L}$. towards mite-infested brood cells as a defense mechanism against the ectoparasitic mite Varroa jacobsoni Oud., Ph.D. theses, RheinischeFriedrich-Wilhelms-Universität, Bonn.

Boecking O., Drescher W. (1994) Rating of signals which trigger Apis mellifera $\mathrm{L}$. bees to remove mite-infested brood, Apidologie 25, 459-461.

Boecking O., Drescher W. (1998) Research on Varroa resistant traits in European honey bee races, EUROBEE AIR3-CT94-1064, EU, Brussels, final report, $22 \mathrm{p}$.

Boecking O., Ritter W. (1993) Grooming and removal behaviour of Apis mellifera intermissa in Tunisia against Varroa jacobsoni, J. Apic. Res. 32, 127-134.

Boecking O., Spivak M. (1999) Behavioural defenses of honey bees against Varroa jacobsoni Oud., Apidologie 30, 141-158.

Boot W.J., Calis J.N.M., Beetsma J., Dong M.H., Lan N.K., Tran V.T., Le Q.T., Nguyen H.M. (1999) Natural selection of Varroa jacobsoni explains the different reproductive strategies in colonies of Apis cerana and Apis mellifera, Exp. Appl. Acarol. 23, 133-144.

Brødsgaard C.J., Ritter W., Hansen H., Brødsgaard H.F. (2000) Interactions among Varroa jacobsoni mites, acute paralysis virus, and Paenibacillus larvae larvae and their influence on mortality of larval honeybees in vitro, Apidologie 31, 543-554.

Gramacho K., Gonçalves L.S., Rosenkranz P. (1997) Temperature measurements of living and killed ('pin test') honey bee brood (Apis mellifera) Apidologie 28, 205-207.

Gramacho K., Gonçalves L.S., Rosenkranz P., De Jong D. (1999) Influence of body fluid from pin-killed honey bee pupae on hygienic behaviour, Apidologie $30,367-374$

Guerra J.C.V., Gonçalves L.S., De Jong D. (2000) Africanized honey bees (Apis mellifera L.) are more efficient at removing worker brood artificially infested with the parasitic mite Varroa jacobsoni Oudemans than are Italian bees or Italian/Africanized hybrids, Genet. Mol. Biol. 23, 89-92. 
Guzman-Novoa E., Vandame R., Arechavaleta M.E. (1999) Susceptibility of European and Africanized honey bees (Apis mellifera L.) to Varroa jacobsoni Oud. in Mexico, Apidologie 30, 71-77; 173-182.

Masterman R., Smith B.H., Spivak M. (2000) Brood odor discrimination abilities in hygienic honey bees (Apis mellifera L.) using proboscis extension reflex conditioning, J. Insect Behav. 13, 87-101.

Nation J.L., Sanford M.T., Milne K. (1992) Cuticular hydrocarbons from Varroa jacobsoni, Exp. Appl. Acarol. 16, 331-334.

Palacio M.A., Figini E.E., Ruffinengo S.R., Rodriguez E.M., Del Hoyo M.L., Bedascarrasbure E.L. (2000) Changes in a population of Apis mellifera L. selected for hygienic behaviour and its relation to brood disease tolerance, Apidologie 31, 471-478.

Rosenkranz P. (1999) Honey bee (Apis mellifera L.) tolerance to Varroa jacobsoni Oud. in South America, Apidologie 30, 159-172.

Rosenkranz P., Tewarson N.C., Singh A., Engels W. (1993) Differential hygienic behaviour towards Varroa jacobsoni in capped worker brood of Apis cerana depends on alien scent adhering to the mites, J. Apic. Res. 32, 89-93.

Rosenkranz P., Fries I., Boecking O., Stürmer M (1997) Damaged Varroa mites in the debris of honey bee (Apis mellifera L.) colonies with and without hatching brood, Apidologie 28, 427-437.

Rothenbuhler W. (1964) Behavior genetics of nest cleaning behavior in honeybees. I. Response of four inbred lines to disease killed brood, Anim. Behav. 12, 578-583.

Spivak M., Downey D. (1998) Field assays for hygienic behaviour in honey bees (Hymenoptera: Apidae), J. Econ. Entomol. 91, 64-70.

Spivak M., Reuter G.S. (1998) Performance of hygienic honey bee colonies in a commercial apiary, Apidologie 29, 291-302.

Vandame R. (1996) Importance de l'hybridation de l'hôte dans la tolérance à un parasite. Cas de l'acarien parasite Varroa jacobsoni chez les races d'abeilles Apis mellifera européenne et africanisée au Mexique, $\mathrm{Ph} . \mathrm{D}$. dissertation, Université Claude Bernard Lyon 1, France. 